\title{
22: 18303863-18331084
}

National Cancer Institute

\section{Source}

National Cancer Institute. 22: 18303863-18331084. NCI Thesaurus. Code C41983.

Physical location of COMT_Gene 